\title{
WHEN COMPELLED TO FB AROUND ACADEMIC TEXTS: POSTGRADUATE STUDENTS REFLECTED ON THEIR ONLINE EXPERIENCE
}

\author{
Sarimah Shaik Abdullah ${ }^{1}$, Aizan Yaacob \& \\ Fauziah Abdul Rahim \\ School of Education and Modern Languages \\ Universiti Utara Malaysia
}

${ }^{1}$ Corresponding author: sarimah@uum.edu.my

\begin{abstract}
Purpose - This paper is part of a larger study which explored postgraduate students talk around academic texts via Facebook (FB). Our exploration is largely guided by the idea of reading as a social practice. In this paper, we specifically focus on the students' reflections of their online experience of talking around academic texts.

Method - The qualitative data used in this paper were derived from students' reflective diaries, students' FB interactions, and informal conversations and were collected from a group of students (27) attending a master's class in distance learning mode. Thematic analysis was conducted to examine the themes that emerged to represent their reflections.

Findings - The students' reflections were grouped into two major categories: convenience and facilitation of learning. Students' reflection on the convenience afforded by the FB talk centered mainly on the idea of distance and time. Their reflections on the facilitation of learning were broken down into the following themes: safe environment to explore, social support, self-regulation and autonomy. A separate category, "FB entries need responding", was assigned to students' comments about the importance of lecturer's and group members' feedback.
\end{abstract}

Value - This study revealed the potential of FB as a convenient, safe and an informal avenue for students to share their understandings and reading-related problems. The informal nature of their FB 
experience supported free exploration of ideas without the worry of having to appear "clever".

Keywords: social media, adult learners, academic reading, talk around text

\section{INTRODUCTION}

Reading assigned materials such as research articles from scholarly journals, is part and parcel of the learning process for postgraduate learners. Instructors often insist that students read prior to class meetings as this can help them participate actively (Lineweaver, 2010; Sappington, Kinsey \& Munsayac, 2002; Wandersee, 1988). However, students often resist the task (Lei, Bartlett, Gorney \& Herschbach, 2010).

At the master's level, reading can be demanding and difficult as students are faced with unfamiliar concepts and long articles (Alverman \& Qian, 1994; Taraban, Rynearson \& Kerr, 2000). The challenge may be intensified for students who read in English as a second or foreign language as most research articles are in English. Limited proficiency can make reading very taxing and time consuming, especially for part-time master's students studying in long distance mode, who have to juggle between their professional commitments, personal commitments and their academic studies commitments (Kaur \& Thiyagarajah, 1999; Ross-Gordon, 2011). Given these various challenges, many may choose not to read, resulting in a "major breakdown" in class discussions, as well as assignment completion and exam performance (Sappington et al., 2002). Additionally, it has been found that students do not read when reading is not formally assessed (Connor-Greene, 2005).

To overcome the problem of non-reading, instructors may give quizzes (Connor-Greene, 2000; Marchant, 2002), graded questions (Uskul \& Eaton, 2005), and written assignments (Connor-Greene, 2005) to increase student readiness. However, as Thorne (2000) pointed out, students often view these ways of encouraging them to read as punitive.

Guided by the social constructivist perspective on reading, our literature search for non-punitive interventions revealed face to face talk around text programmes to facilitate struggling readers at school, 
such as Reciprocal Teaching (RT) (Palincsar \& Brown, 1984), Collaborative Strategic Reading (Klingner, Vaughn \& Schumm, 1998) and expository text talk (Reichenberg, 2008). Programmes such as RT (Hart \& Speece, 1998) and expository text talk (Jang, 2007) were also found applicable to undergraduate students, but not to postgraduate students. Face to face talk around text, however, would not suit busy distance education learners. Our examination of online alternatives revealed a number of tools to facilitate distance learning such as Blogs, Blackboard, and Learning Management System (LMS) (Cloete, de Villiers, \& Roodt, 2009). Nonetheless, the application of these tools was highly structured, formal and nonconversational (Hungerford-Kresser, Wiggins \& Amaro-Jimenez, 2011-2012; Lineweaver, 2010). Since our intention was to motivate postgraduate struggling readers to freely and jointly talk around academic texts in nonthreatening learning environment, we resorted to implementing the talk on Facebook (FB), an informal online social setting that is reported to be informal and supportive of interactive discussions and of which most students are familiar (Visagie \& de Villiers, 2010). In this paper, we examine the students' reflection of their online experience talking around academic texts.

\section{READING AS A SOCIAL PRACTICE}

Reading, from the social constructivist perspective, is viewed as more than a mere cognitive process of an individual reader interacting with the text. It includes the interaction with other readers and "the processes by which those readers go about making sense of text ideas" (Kucan and Beck, 1997, p. 289). Within this perspective, there is an emphasis on joint construction of meaning with students having their teacher and/or other students serving as resources in their attempts to develop an understanding of text ideas (Kucan and Beck, 1997). When the interaction involves dialogue among readers, the students have what Kucan and Beck call "multiple resources" at their disposal as they deal with the text. These resources include the talk, the peers (this includes multiple background knowledge and experiences, plus language knowledge), possibly the teacher (this includes teacher's expertise and background knowledge), the text, and the activity of interpreting, challenging, refuting and reaching understanding. In other words, when working together and using dialogue as a means to reach the goal of understanding, the task of constructing understanding is distributed among all participants 
(Brown, Ash, Rutherford, Nakagawa, Gordon, \& Campione, 1993). Talk around text is commonly featured in literature discussion (Pantaleo, 2011). It is a small group discussion activity, often associated with literary texts. It relates to the idea of aesthetic reading (Rosenblatt, 1978) which assumes that readers bring to the text their own experiences and knowledge and used them to construct meaning of the text. In other words, readers do not read to reproduce information alone, but to interact with the text and to construct their own meaning of the text based on their own background knowledge, experiences and assumptions.

Talk around text has been studied in the context of primary classrooms (Eeds \& Wells, 1989; Maloch, 2002; Purdy, 2008), in middle school classrooms (Pantaleo, 2011), and for middle grade English language learners (Cowgill, 2008). It has been argued that such group talk allows students to engage in discussions that are relevant to them, thus promoting deep and meaningful engagement with texts (Almasi, 1996: Eeds \& Wells, 1989).

There have been attempts to apply talk around text for expository texts, for instance in Reciprocal Teaching (Palincsar \& Brown, 1984) and Collaborative Strategic Reading (Klingner, Vaughn \& Schumm, 1998) at school level and RT at university level (Hodge, Palmer \& Scott, 1992; Al-Hilawani, Merchant, \& Poteet, 1993). However, the talk in these instances were structured and limited to comprehension maintenance. Reichenberg (2008) and Jang (2007) have attempted to apply the idea of talk (as promoted in literary discussions) to expository texts. Reichenberg (2008, p. 20) argues that as in literary texts, expository texts too are read with "authors in mind" who are "potentially fallible." This resonates with Bernhardt's (1991) argument that in all kinds of reading, readers construct and reconstruct meanings of texts. Reichenberg studied teacher-led talk around text among 17-year-old students and found that when teachers engaged in open questions and allowed for students to talk about the text, they naturally encouraged active reading whereby students put in efforts to explore ideas in the text and made numerous inferences and reflections. In Jang's (2007) study, college students found the combination of talk and writing of expository texts was rich and interesting: Talk helped them make explicit their thoughts, facilitated their understandings of science concepts and promoted active learning. When students began to 
feel that their opinions count and reading is not just a reproductive account of the author's ideas, they would begin to explore and make meaningful connections with the texts (Hadjioannou, 2007; Maloch, 2002; Shaik-Abdullah, 2005).

\section{$F B$-ING AROUND ACADEMIC TEXT}

As regards online talk, Lineweaver (2010) attempted to increase the number of students who read before class by requiring her students to participate in asynchronous online structured discussion of their reading, through Blackboard, an online classroom management program commonly used on campus. The assignment required students to post at least three substantive comments ("several sentences of observation, a several-sentence comment on other people's questions or observations, or a thoughtful question with a rationale for asking it") on three different days. Although Lineweaver found little effect of students' online discussion on examination performance, students reported better understanding of class lectures as online discussion provided opportunities to talk around text, to create their own examples and to apply course material to their everyday lives. The online talk was also found to improve the quality of classroom discussions (Lineweaver, 2010). However, as this was an asynchronous discussion, the students' talk was non-interactive, highly structured and limited to predetermined areas of contribution, thus minimizing opportunities for students to freely express their ideas.

Other studies on online discussion highlight the types of tools used for purposes not related to reading and text talk. These include Blackboard for online discussion for academic language socialization (Beckett, Amaro-Jimenez \& Beckett, 2010); blog for undergraduate writing (Nadzrah \& Kemboja, 2009); blog for undergraduate listening to literature (Ganakumaran, 2006); blog for reflection (Hungerford-Kresser et al., 2011-2012). Beckett et al. (2010) studied academic online discussion (OAD) as an extension of classroom discussion for Masters and $\mathrm{PhD}$ students within multiethnic settings and found that students perceived OADs highly positively and used them as an online community for academic discourse socialization and appropriation. Students also expressed frustration and disappointment regarding professor's presence and grading. Nadzrah \& Kemboja, (2009) and Ganakumaran (2006) 
found the potential of online postings to enable less confident L2 learners to express themselves, as it reduces anxiety as they work with peers. Hungerford-Kresser et al. (2011-2012), on the other hand, found students who claimed that blogging was just a response, not a conversation. In giving responses, the students felt they had to give unique and original responses. This resulted in the students feeling discontent with the use of blog as they felt it denied them the freedom to express their own ideas.

Facebook (FB) use is relatively new in formal learning. FB is commonly known as an online social network that allows users to connect with friends, family members and share resources "within user-created networks with a variety of different permission levels for private or public posting" (Gonzales \& Vodicka, 2010, p. 9). Its usage is commonly perceived as an informal mode of communication (Kiser \& Porter, 2011), and seldom explored as a formal network for learning (Baran, 2010). Since 2011, FB can be used in both asynchronous and synchronous mode. According to Revere \& Kovach (2011), social media such as FB support the "exchange of "social information" which online students in other formats often report missing due to the absence of face-to-face meetings.

Baran (2010) cited studies which found that students generally view FB as a social technology rather than a formal teaching tool (Selwyn, 2009; Greenhow \& Robelia, 2009; Selwyn \& Grant, 2009; Usluel \& Mazman, 2009). Pilgrim and Bledsoe (2011) have explored FB's potential use for learning among educators as they can find ideas for classroom practices as well as learn about trends and issues in education. Baran (2010) made attempts to use FB for students to discuss videos, links and pictures and investigated what the students thought about the incorporation of FB in their coursework. Students in Baran's study believed that FB could be used for knowledgesharing in formal education and many indicated that communicating with their classmates helped to motivate them in their learning. A more recent study by Meishar-Tai, Kurtz \& Pieterse (2012, para. 39) found students viewing of their FB group activities as a "stimulator of participation," and "even passive students had the ability to express their presence on the FB by indicating "like" on chosen posts."

The use of FB is not without problems. Cloete et al. (2009) reported some disadvantages of working on FB, such as students may be exposed to various advertising information. In addition, online 
safety and privacy could be problematic as students' profiles may be accessible to anyone on the internet (Towner \& vanHorn, 2007). Further, some students may not have access to the internet and hence, cannot access the FB. There is also the possibility of students getting distracted and spending more time on FB to socialize than to work (Cloete et al., 2009).

Given the newness of FB and the informal social communication setting that it provides, our study examines its potential for use among postgraduate students to talk around the academic texts, as a way to motivate them to read and to encourage sharing of ideas, understandings and reading-related problems in non-structured way. We specifically explore the students' reflections on their FB experience talking around academic texts.

\section{METHODOLOGY}

\section{The Text Talk on Facebook}

To facilitate the students' engagement, we introduced online talk around text to an intact group of 27 students taking an Educational Psychology master's course via distance learning. The class met four times throughout the entire semester (March to May 2011). Class meetings were held in the east coast region of Malaysia.

Prior to the second and fourth class meeting, the students were required to choose and read from a list of articles and discuss the article on FB. To eliminate the students' tendency to heavily rely on the instructor's facilitation, the instructor (who is also the first author) chose to minimize her own participation in the online discussion for fear that her comments would "overshadow student comments or steer the discussion in a more top heavy direction" (Collison, Elbaum, Haavind, \& Tinker, 2000). Her involvement was limited to prompting the students when they were not discussing, or when they were merely retelling what they had read. The talk was meant to be a free discussion avenue, where students were free to explore and this meant they could use the online talk as an avenue for dealing with difficulties and lack of understanding. However, suggestions were made to include in their discussion the elements of research (theoretical underpinnings, research gap, 
research objectives, methodology, and findings) and how the studies related to their own teaching context. The talk was modeled in the classroom. Ground rules for managing their group discussions were highlighted (Mercer, 2000).

The online talk was graded. We were concerned that the students would not participate if the talk was not graded (Lei, et al, 2010; Graham \& Scarborough, 2001). Furthermore, given the amount of time that the students had to spend reading before discussion, it seemed appropriate and ethical to award them grades for their effort. What was discussed online was included in class discussion so that any confusions, misunderstandings, and concerns could be further clarified and elaborated.

The students were mostly familiar with FB, as most had FB accounts and were able to create their group account relatively quickly. They formed small groups (4-5 per group), created their own group FB, giving a unique name to it, set the group to private and accessibleonly-by-members mode, and allowed access to the instructor. The students could access their group discussion by means of handheld devices and computers.

\section{Data Collection}

To understand the students' FB experience talking about the text, we employed qualitative research approach. Our main source of data was their reflective diaries (Moon, 1999) and printed record of their FB interactions. Other methods such as the interview were not feasible, as the students were busy, and the only time to meet them was during class time.

The reflective diaries were used to assess students' views of what they were doing and the challenges that they faced as they participated in the text talk. Given their busy schedules, the students were requested to reflect only twice throughout the semester. The students submitted their reflections by hand or by email. The students' reflections were compared to their FB talk as a way to triangulate data.

Ethical guidelines were observed which included getting their consent and keeping their identity hidden so that they could express themselves freely (Marshall \& Rossman, 1999). The students were also assured that their reflective diaries would only be read after 
the final course mark had been released. This was to give them confidence that their reflections in no way would affect their course grades. Finally, to protect the students' privacy, we use pseudonyms in the place of real names to report our findings.

In analyzing the data, we used open coding (based on constant comparative methods) (Strauss \& Corbin, 1998) to identify themes to represent repeated ideas that emerged across the students' FB text talk and reflections about their experiences. We assigned labels to sections of text from the FB interaction, and the reflective diaries, as a means to identify patterns in the students' reflection and discussion. We engaged in peer examination to ensure that our analysis was reliable and that our own biases and predispositions would not affect our interpretation of the data (Gray, 2004).

\section{FINDINGS AND DISCUSSION}

The students' reflections on their FB experience could be grouped into two major categories: convenience and facilitation of learning. Their reflections on the convenience afforded by the FB experience centered mainly on the idea of distance and time. Their reflections on facilitation of learning were broken down into the following themes: safety, social support, self-regulation and autonomy, and lecturer's and group members' feedback.

\section{FB Experience as a Convenience}

By and large, the students perceived the online talk around text as a convenience for them, especially in terms of time and mobility. The distance learning mode of the programme meant that they could not meet up face to face outside class time to complete their course assignments. Having the convenience of online talk enabled them to meet online and thus execute their group task without the need to be physically present:

[It] can overcome the problem of time. (Masri, reflective diary) It saves time... to make oneself be present with distant friends. (Jamal, reflective diary)

Distance learning students... [FB as a] facility to work in groups. (Faiz, reflective diary)

(*Italic to indicate reflections and discussions conducted in mother tongue) 
Also expressed was the idea that they could participate in discussions at their own convenience. As FB could be both synchronous and asynchronous, the students had the choice about how to manage their group talk. Some chose to be online at the same time, while others chose to go asynchronous. In fact, they could go away and come back to the discussion when they were ready. Further, the fact that it could be done outside class and anywhere convenient suited their needs as busy adults. The flexibility in how they handled their virtual meetings provided them with the ability to manage their time and life accordingly.

[We] can discuss at our own free time. (Zaki, reflective diary)

I could manage study and work more effectively and with less stress. (Hayat, reflective diary)

[There is] no need to leave the house, and daily routines like attending to the children... no need to explain to the husband to go out. (Muna, reflective diary)

Nonetheless, the convenience associated with their FB experience was not without challenges, one of which was the poor Internet connection in some areas of the state in which the students lived and worked (Cloete et al., 2009). The poor Internet connection was blamed for the disruption to their discussion, especially since they only had a certain period of time that they could meet up online for synchronous discussion, which was usually held at night.

Broadband access is limited in rural areas. (Nik, reflective diary) Oh this is stressful, the internet is down, I would like to join too... helpppp. (Alia, FB entry, May 3, 2011 at 10:46pm).

In addition to this, there were instances when the students' postings were not immediately available to all who were online at the same time. For instance, those using handheld devices might have posted their comments, but these comments could not be read by their group members until later, thus disrupting their attempts for smooth synchronous discussion.

Norma: No wonder I felt my questions were not answered... I was talking to myself...hi hi...( May 4, 11.24 pm)

Latifah: Norma, I have the same problem... I received [your message] on BB but the computer did not update your comments. (May 4, 2011 at 11:22pm) 
In this case, the students had to put in effort to revisit their earlier postings to make sure that they did not leave any responses unattended to. However, our examination of the FB data revealed that most of the postings were left unattended to resulting in disjointed discussion.

\section{FB as a Safe Environment to Explore}

The students expressed their feelings of comfort and safe when they participated in the online talk. The environment promoted openness which allowed for the students to express their understandings and misunderstanding honestly and sincerely. They felt comfortable expressing their views without feeling embarrassed, and for some, the fact that their views were expressed in writing and not verbally could overcome the lack of confidence in their ability to speak and listen. This is the case perhaps because when done verbally and face to face, they felt exposed as they had to put in energy at expressing their ideas and at the same time be watchful of their oral language. On the other hand, when working on FB, the students merely had to write their thoughts.

It's more comfortable to express views and pose questions on FB compared to [doing it] in class. (Alia, reflective diary)

...more open and sincere in giving and receiving opinions. (Jamal, reflective diary)

I can express everything that I don't understand or what I understand based on my experience and my reading without feeling embarrassed...Low self-esteem can be reduced-because what is said is in written without "the use of language"(Faiz, reflective diary)

Shy students like Miza, who was often very quiet in class, were able to express their thoughts and ask questions at great length during their FB talk, as was the case in the following excerpt:

Dania In your opinion, why were the children divided into three conditions?... was it based on their levels or how?? (May 3, 2011 at 9:34am)

Miza Dania, I am just giving my opinion as to why the children were divided into three conditions which is strategy+self regulation (22 girls and 19 boys), strategy only (19 girls and 15 boys) and control (15 boys and 23 girls). This may 
be due to the researcher's need to see the effectiveness of the skills in the children's learning. (May 5, 2011 at $1: 20 \mathrm{pm})$

Miza For example, in another journal that I read entitled "Differences in cooperative learning group and problem-based instruction in promoting student learning performance" it was found that there were 2 groups of students, the cooperative learning and the problem based learning. The research was intended to see the level of learning in group without teacher control and another group which is filled with teacher guidance. Research revealed differences between the two. (May 5, 2011 at $1: 29 \mathrm{pm})$

Miza The same goes with the current article, the research investigated if there were differences between the group that used strategy and self-regulation and the group that used only strategy. (May 5, 2011 at 1:31pm)

Dania Ermmm... in this way the researcher can see which of the two ways is more effective and appropriate for use in the children's learning. (May 5, 2011 at 1:33pm)

Dania Oooo... now I understand, thanks Miza. (May 5, 2011 at $11: 42 \mathrm{pm})$

Miza was very informative in trying to help her friend understand the reason behind the use of three groups in the experimental study they were engaging in. Miza explained the need for the grouping as applied in the experimental design by referring to her own familiarity with a similar study that she had read in the past. Her explanation was lengthy, something which was never evident during class meetings. This exemplifies the arguments that the online talk can benefit an introvert learner like her and those who have little confidence (Baran, 2010; Beckett et al., 2010; Thomson, 2010) to freely explore the content of their reading. As Miza showed, she was able to provide assistance to help Dania understand the methodological design in the study. Perhaps their online participation provided them with time to formulate and compose appropriate and complete responses (Kassop, 2003; Markel, 2001). As can be seen, Miza did not respond immediately to Dania. Her response came one and a half days after Dania sought help. Miza's talk was open, detailed in her attempt to post what she understood, something which did not happen in the classroom. 
The conversational nature of the students' discussion suggests a very informal way for them to post their ideas or questions. This can be seen in the way the students posted their entries which were written informally. They used a lot of simplified or short form words which they would normally do in texting messages, as the following example shows.

\section{.... akk rasa betul pandangan tu $\underline{\text { bbb}}$ klu $\underline{x}$ silap ... \\ (akk=kakak (I); sbb=sebab (because); $\mathrm{x}=\operatorname{tak}$ (not))}

This way of communicating was not anticipated by the instructor. However, upon noticing the students' relaxed way of communicating, she chose to reserve her evaluation on their talk, so that they would feel free to explore in their communicative interactions.

The relaxed nature of their discussion perhaps allowed for the students to feel they could discuss the texts openly and "transparently" without feeling uncomfortable or embarrassed. This was unlike what was found in Hungerford-Kresser et al. (2011-2012), whose participants felt that their participation in the blogging activities were not conversational and therefore dismissed the freedom for self-expression-blogging became an exercise in which everyone felt they had to say something original. In the FB talk in the current study, the students appeared to be free to express themselves.

Despite the informal and relaxed nature of the discussion, some students did not feel comfortable with this online mode of communication and still preferred the face to face meetings. Among their reasons were the facts that FB lacked the personal touch and possibly observable clues (Pena-Shaff, Martin, \& Gay, 2001), and was somewhat loose in terms of discipline and control as the following diary entries revealed:

We need "live" interaction, because body language and intonation can help our understanding-because FTT (FB text talk) creates miscomprehension or double meaning. (Aziz, reflective diary)

The situation was too loose, too informal that influences members discipline and commitment. (Masri, reflective diary) 


\section{FB Talk Provided the Social Support}

Some of the students also felt that the online talk provided the social support for learning, when they were able to seek help, solve comprehension problems, and resolve any confusions arising from the discussion. The discussion could help them understand the articles. As the earlier excerpt from FB discussion illustrated, Dania, who was not certain about the procedures in doing experimental research, was able to post her question about the experimental design for her groupmates to respond. The students' diary responses revealed the following social supports that they viewed were available during their online talk:

[We] could implement scaffolding technique which enabled group members to complement one another's understanding. (Latifah, reflective diary)

A very meaningful learning approach because the discussion can help group members who have trouble understanding the article to understand it better. (Dania, reflective diary)

Some students found comfort in the concept of "scaffolding" which they picked up from the course and another course to describe the kinds of support they received from their friends and also the kinds of help they gave. Further, as pointed out by one of the students, the social support received during their online talk could increase their motivation level (Hiltz, Shea, \& Kim, 2007; Baran, 2010). The peer support or "peer scaffolding" as another student pointed out appeared to be highly valued by the students.

Friends help friends who don't understand, peer scaffolding,... can increase motivation. (Yusni, reflective diary)

The social environment the students had on FB was something that they felt missing in the classroom. In class, they would be worried about what others would say, about exposing themselves publicly and about how they would be judged by the instructor and course-mates.

When providing help, there were instances to show that the students did not merely feed their group members with the immediate answers. Instead, they guided their friends to find where in the article they would find the information to overcome their confusions. This is illustrated in the following instance: 
Latifah: Norma do you understand the second objective? (April $11,10.45 \mathrm{pm})$

Alia: I think, to understand the second objective ("other factors which influence information processing"), you can reread the discussion on page $782 \ldots$ which says "a student's ability to understand and read text depends also on the language used and problems often faced". (April $12,12: 58 \mathrm{am})$

Besides getting help and guidance from their friends and enhancing motivation, the social supports were perceived to reduce boredom associated with attempts to read dull and difficult texts alone.

Reading without sharing, it'll be dull and boring. (Alia, reflective diary)

\section{FB Promotes Self-Regulation and Autonomy}

For some students, the online talk around text "increased their sense of self-regulation" since their FB interaction required early preparation in terms of reading in advance and getting ready before they could actively discuss the texts. This encouraged them to manage their study time well, and this too forced them to be accountable for the running of their group discussion (Li \& Beverly, 2008). The students reflected on their feeling of accountability or a need to be ready for the group to function well as they talked about the importance of the "self getting ready in advance so that active discussion could be attained" (Alia, reflective diary), "commitment towards oneself and group members" (Laila, reflective diary) and "instilling in oneself the value of responsibility towards group members" (Faiz, reflective diary). As another student put it,

It enabled me to organize my study time because FTT reminds me of my commitment to myself and group members.(Laila, reflective diary)

This would probably be different if the students waited to discuss the articles in class with the lecturer. As we have experienced in the past, the bulk of the discussion would be put on the lecturers' shoulder, and the lecturer might be perceived as the "all knower", and whose knowledge is treated as unquestionable (Saljo, 1982). 
When the lecturer was perceived as such, this might be a good reason for non-reading students to think that what they did not know or did not read would be taken care of by the instructor.

The developed sense of responsibility compelled the group members to remind one another to keep the discussion going, as the following example illustrates:

Hani: $\quad H m m m . .$. don't you want to continue with the discussion ... let's continue... $30 \%$ is plenty, friends...(FB entry, April $29,4.07 \mathrm{pm})$

In the above example, Hani prompted her group members to move on with their discussion. She reminded them of the seriousness of the FB discussion which was 30 percent of the final course grade.

In addition, some students also talked about having a degree of autonomy as they could control and direct their own learning (Cavanaugh, 2007). The ability to plan for their own learning enabled some students who had difficulties with reading the text to take time to construct their understanding and work at their own learning rate.

[We] can postpone when needed, and resume whenever we are ready...(Muna, reflective diary)

\section{FB Posting Needs Responding}

The examination of the FB data revealed that students tended to benefit more from the synchronous mode of their FB discussion than the asynchronous mode. When they all met at the same time, the tendency to respond to their friends' postings was greater. Their discussions were more interactive than when the groups opted for asynchronous discussion.

Discussions should be done synchronously because feedback can be given immediately. If done at different times, we'll forget about the issues raised. (Latifah, reflective diary)

When they went asynchronous, there was a great tendency for the students to merely post their thoughts without waiting for or without getting any feedback, and thus their postings became 
a mere lengthy listing of information recall. In this situation, the discussions appeared to represent "individualized participation" as described by Yeh (2010) to typify students' who merely posted their entries without waiting for responses. When done this way, some students might post their comments to fulfill the requirement for the online talk but in no way reflected a meaningful discussion that was intended, as the following example reflects:

Zaki According to Pintrich (2000), self-regulation is an active and constructive process in which students determine their learning goals, and then strive to monitor, regulate and control their cognition, motivation and behavior, to work based on goals and environmental contexts. (May 9, 2011 at 9:40pm)

Zaki Glaser and Brustein's (2007) research was to see the effectiveness of strategies and self-regulation towards the improvement in the ability in writing essays among fourth grade students. (May 9, 2011 at 9:47pm)

Hayat Based on Pintrich's (2000) definition of self regulation, to enable students to be skillful, it will require specific exposure and training. Surely this method can be used with advanced learners but what about weak and average students, can they give the same commitment? (May 10, 2011 at 12:44am)

Rusdi The objective is to show that self regulation is effective behavior in that it increases the ability to regulate strategies, to monitor strategies and to transfer strategies for given assignments. (May 12, 2011 at 4:22am)

This type of posting perhaps can be explained in a number of ways. First, some students might have misunderstood the purpose of the talk, and thus in some cases (especially at the initial stage), tended to post their translation of what was read. The instructor monitored the students' discussion from time to time, and reminded the groups about how to discuss the article. In the following instance, when the instructor found that a group was merely recalling the text, she posted:

You have started your discussion, I see... congratulations! My hope is that you're not just translating and recalling information alone... you need to discuss and give views based on what you know about research, and about the learning theory used in the article.( March 9, 2011,11.56 am) 
Despite the instructor's reminders, some groups continued to face difficulties in posting their ideas and ended up merely posting their translations of the ideas they got from reading.

Another more feasible explanation for the mere postings could be because of the difficulty of understanding the text. Some students pointed out in their reflection that the "article was too long and difficult to understand" (Dania, reflective diary) and "the language of the article was difficult, it takes time [to read]" (Miza, reflective diary). This could have prevented active engagement as in the following case:

Fariza: How do we find the theoretical framework for this study? (May 9, $1.30 \mathrm{pm}$ )

Zaleha: Yeah, I still can't figure out what the theoretical framework is, that is why I'm still not well-versed in theoretical framework... what shall we do? (May 10, $9.03 \mathrm{pm})$

Siti: I too cannot understand the article. (May 18, 7.26pm)

Some students related the problem of responding to postings to everyone's availability to be online at the same time.

Group members who have different assignments that make it difficult to meet online at the same time... (this is different from the face to face discussion). (Masri, reflective diary)

Given the difficulty with setting time to meet, some groups attempted to do asynchronous discussion. However, their FB discussion revealed many un-responded postings or delayed responses-“late in getting responses from group members... discussion became slow" (Zaki, reflective diary). As found in other kinds of online participation, Revere \& Kovach (2011) pointed to the frustrations due to posting delays in discussion board communication as students needed immediate feedback.

The students also reflected on the need for frequent instructor feedback. Although the instructor had advised that her involvement in the discussion would be limited to reminding them to discuss, the students insisted that frequent feedback from the lecturer was needed. 
The lecturer needs to be online to stimulate interest and commitment of the group members. (Jamal, reflective diary) Need to get involved more frequently so that we do not get easily satisfied with our own interpretations and go off tangent. (Nik, reflective diary)

As these students pointed out, the lecturer's feedback and online presence was much needed for the purpose of stimulating interest, to provide guidelines and to evaluate their participation (Baran, 2010; Beckett et al., 2010).

\section{CONCLUSION}

The collaborative and nonthreatening nature of the face to face text talk has been shown in the past to enable students at school and at undergraduate level to construct understanding together. For postgraduate distance education learners, face to face discussion could be difficult to set up due to the students' busy schedules and therefore would require a more convenient alternative such as an online collaborative discussion. Our examination of online collaborative learning alternatives such as the LMS's revealed learning activities that are highly structured, formal and controlled (Meishar-Tai, 2012). In this study, we introduced to a group of distance education students the use of $\mathrm{FB}$ as an informal online setting to talk about their reading together. This paper reports our findings of their reflection of their experience FB-ing around academic texts.

We found that FB has the potential as an informal setting for students to share their thoughts and problems relating to their academic reading. The distance education postgraduate students perceived the ease that the technology offered in terms of time and mobility conveniences, as they could conduct their discussion virtually at times of their own choice without leaving the comfort of their home. This flexibility makes FB a useful alternative for online learning alongside other online tools, such as the LMS's. Alas, in remote areas, poor access to the Internet could prevent the students from getting online and disrupt a potentially fruitful learning experience (Cloete et al., 2009). Further, as the students were using different devices (i.e. Blackberry, i-Phone, and laptop) to access the FB, on 
occasions, their postings were not immediately available to all group members. This may result in delayed responses which could prevent active discussions (Revere \& Kovach, 2011).

Synchronous discussions appeared to be more fruitful than asynchronous discussions, as they tended to be more interactive and FB entries were more immediately attended to. Schroeder \& Greenbowe (2009) reasoned that the greater volume of activity in a synchronous discussion could be due to the fact that "students were already accessing Facebook for personal use" and hence, checking in on their group discussion would not be a problem. In our case, the greater participation in a synchronous discussion seemed to be because the students had fixed the time for everyone to meet online. Meeting this way enabled the students to attend to problems and seek help immediately. Groups that did not fix the time and opted for asynchronous talk had difficulties maintaining their discussion. The fact that most of them were active FB users did not help them make regular visits to their group FB. While doing asynchronous discussion may provide a leeway for busy students to manage their time and to plan for when to be online, their other commitments and preferences may prevent active participation. Further, asynchronous meetings limit the chances for gaining immediate feedback and support, so the students would have to attend to the difficult academic texts alone. This could create the feeling of isolation (Rovai, 2002) and reduce their interest to read and participate.

In terms of support for learning, the students reflected on the way the FB experience provided the support and safe context for exploration, and at the same time promoted a sense of responsibility in ensuring that the talk takes place accordingly. The students also talked about how their collaboration helped them overcome some of the difficulties in understanding the text. As we focused mainly on the students' reflection of their FB experience, we have no way of determining the actual quality of the discussions. However, as the excerpt in an earlier section showed, even the shiest students were willing to talk about the articles, something that might not have happened in a face to face situation. Perhaps the informal and conversational way of discussing reduced the feeling of anxiety. In addition, the time allowance for them to reflect and think about what they wanted to say, gave the students the room to safeguard an FB entry by reviewing it before posting it on the FB wall for their groupmates to read. 
At the same time, the students reflected on the importance of assuming a certain degree of control over their learning, as they felt accountable for the success of their group discussion (Beckett et al, 2010; Meishar-Tai et al., 2012). A great importance was also placed on the participation of the instructor whose online presence was needed to provide guidance and help, and more importantly as a way to motivate, reduce frustrations and give feedback as regards their online involvement (Anderson et al., 2001). Despite the need to encourage the independent exploration of the text, we realize that it is important for the instructor to intervene when some groups struggle to keep their discussion going. The intervention could be in the form of modeling the discussion online and mediating the discussion by providing some open questions as was applied in Reichenberg (2008). Modeling the talk in the classroom alone, as was done by the instructor in this study, may not be sufficient.

Certainly, not all students were ready to adopt this way of learning, given the lack of face-to-face interaction that they were used to (Baran, 2010). Further, the relaxed and informal nature of the discussion could compromise on control and discipline, as highlighted in Cloete et al. (2009).

Our findings suggest a possibility for using FB to talk around text, in addition to other forms of online learning modes, such as Blogs and Blackboard, thus acknowledging the pedagogical potentials that online social networks may have (Dalsgaard, 2008; MeisharTai, 2012). Our discussion is, nonetheless, limited to understanding the students' reflections on their online experience. We are in no position to talk about the quality of their interaction and their ability to appropriate the academic discourse language in their discussion. This will require a different paper and a different framework for looking at the nature of their talk i.e. based on academic language socialization as studied by Beckett et al. (2010). Another possible area for exploration would be the examination of the differences between male and female students' participation in the FB text talk, as our presentation of data seemed to suggest that female students tended to show greater participation than the male students. We also see the possibility for a future study to explore the instructor's role in encouraging online postings, as this can provide some understanding about the process and challenges in promoting this way of learning. To make online text talk work, students need to develop the 
understanding that the instructor's role would naturally be different from the traditional classroom teaching, in which the instructor transmits the knowledge and the students listen. In student centered environment such as attempted in our study, students need to learn to take ownership of their own learning, be responsible, and not expect the instructor to feed them with information all the time. To help students achieve this awareness, the instructor needs to make time to gradually and progressively guide students towards becoming independent learners. Hence, clear instructions, clear evaluations, speedy and quality responses (Meishar-Tai et al., 2012) and plenty of motivating words are needed while at the same time the instructor maintains the informality of the FB environment that promotes openness and safety to explore.

\section{REFERENCES}

Al-Hilawani, Y. A., Merchant, G. J., \& Poteet, J. A. (1993). Implementing reciprocal teaching: Was it effective? Paper presented at the annual meeting of the Midwest Association of Teachers of Educational Psychology. Anderson, In. (ERIC Document Reproduction Service No. ED 363 614).

Almasi, J. F. (1996). The nature of fourth graders' sociocognitive conflicts in peer-led and teacher-led discussion of literature. Reading Research Quarterly, 30(3), 314-351.

Alvermann, D. \& Qian, G. (1994). Perspectives on secondary school reading: Implications for instruction. Reading \& Writing Quarterly: Overcoming Learning Difficulties, 10, 21-38.

Baran, B. (2010).Facebook as a formal instructional environment. British Journal of Educational Technology, 41(6), 146-149.

Beckett, G. H., Amaro-Jimenez, C., \& Beckett, K.S. (2010). Students' use of asynchronous discussions for academic discourse socialization. Distance Education, 31(3), 315-335. Bernhardt, E. B. (1991). Reading development in a second language: Theoretical, empirical and classroom perspectives. New Jersey: Ablex.

Brown, A. L., Ash, D., Rutherford, M., Nakagawa, K., Gordon, A., \& Campione, J. C. (1993). Distributed expertise in the classroom. In G. Salomon (Ed.), Distributed cognitions: Psychological and educational considerations. Cambridge: Cambridge University Press. 
Cavanaugh, C. (2007). Effectiveness of K-12 online learning. In M. Moore (Ed.), Handbook of distance education ( $2^{\text {nd }}$ ed.). Mahwah, NJ: Lawrence Erlbaum.

Cloete, S., de Villiers, C. \& Roodt, S. (2009). Facebook as an academic tool for ICT lecturers. Proceedings of the SACLA 2009 Conference. Retrieved from http://portal.acm.org/ citation.cfm?id

Collison, G., Elbaum, B., Haavind, S., \& Tinker, R. (2000). Facilitating online learning: Effective strategies for moderators. Madison, WI: Atwood Publishing.

Connor-Greene, P. A. (2000). Assessing and promoting student learning: Blurring the line between teaching and testing. Teaching of Psychology, 27, 84-88.

Connor-Greene, P. A. (2005). Fostering meaningful classroom discussion: Student-generated questions, quotations, and talking points. Teaching of Psychology, 32, 173-175.

Cowgill, Jennifer Anne, (2010). Talk opportunities around text and the responses they elicit from middle level English language learners. Dissertation Abstracts International Section A: Humanities and Social Sciences, 71(4-A), 2010. pp. 1245.

Dalsgaard, C. (2008). Social networking sites: Transparency in online education. Paper presented at EUNIS 2008 VISION IT - Vision for IT in Higher Education (June 24-27, 2008). Retrieved from http://eunis.dk/papers/p41.pdf

Eeds, M., \& Wells, D. (1989). Grand conversation. Research in the Teaching of English, 23(1), 4-29.

Ganakumaran, S. (2006). Sticability in online autonomous literature listening programme: Strategies for sustaining learner interest and motivation. Malaysian Journal of ELT Research, 2, 8096. Retrieved from www.melta.org.

Gonzales, L. \& Vodicka, D. (2010). Top ten internet resources for educators. Leadership, January/February, 8-37.

Graham, M. \& Scarborough, H. (2001). Enhancing the learning environment for distance education students. Distance Education, 22(2), 232-244.

Greenhow, C. \& Robelia, E. (2009). Informal learning and identity formation in online social networks. Learning, Media and Technology, 34, 2, 119-140.

Gray, D. E. (2004). Doing research in the real world. Thousand Oaks: Sage. 
Hadjioannou, X. (2007). Bringing the background to the foreground: What do classroom environments that support authentic discussions look like? American Educational Research Journal, 44(2), 370-399.

Hart, E. R. \& Speece, D. L. (1998). Reciprocal teaching goes to college: Effects for postsecondary students at risk for academic failure. Journal of Educational Psychology, 90(4), 670-681.

Hiltz, S.R., Shea, P., \& Kim, E. (2007). Using focus groups to study ALN faculty motivation. Journal of Asynchronous Learning Networks 11(1), 1-20. Retrieved from http://jaln. sloanconsortium.org/index.php/jaln

Hodge, E. A., Palmer, B. C., \& Scott, D. (1992). Metacognitive training in cooperative groups on the reading comprehension and vocabulary of at-risk college students. College Student Journal, 26, 440-448.

Hungerford-Kresser, H., Wiggins, J., \& Amaro-Jimenez, C. (20112012). Learning from our mistakes: What matters when incorporating blogging in the content area literacy classroom. Journal of Adolescent \& Adult Literacy, 55(4), 326-335.

Jang, S. -J (2007). A study of students' construction of science knowledge: talk and writing in a collaborative group. Educational Research, 49(1), 65 - 81 .

Kassop, M. (2003). Ten Ways online education matches, or surpasses, face-to-face learning. The Technology Source Archives at the University of North Carolina. Retrieved from http://technologysource.org/article/ten_ways-online_ education_matches_or_surpasses_facetoface_learning

Kaur, S. \& Thiyagarajah, R. (1999). The english reading habits of ELLS students in University Science Malaysia. Paper presented at the Sixth International Literacy and Educational Research Network Conference on Learning, Bayview Beach Resort, Penang, Malaysia.

Kiser, A. I. T., \& Prter, T. (2011). Social networking: Integrating student and university professor utilization. Global Conference on Business and Finance Proceedings, 6(2), 191-196.

Klingner, J. K., Vaughn, S., \& Schumm, J. S. (1998). Collaborative strategic reading during social studies in heterogeneous fourth-grade classrooms. Elementary School Journal, 99, $3-21$. 
Kucan, L., \& Beck, I. L. (1997). Thinking aloud and reading comprehension research: Inquiry, instruction, and social interaction. Review of Educational Research, 67(3), 271-299.

Lei, S. A., Bartlett, K. A., Gorney, S. E., \& Herschbach, T. R. (2010). Resistance to reading compliance among college students: Instructors' perspectives. College Student Journal, 44 (2).

Li, C. S., \& Beverly, I. (2008). An overview of online education: Attractiveness, benefits, challenges, concerns, and recommendations. College Student Journal, 42, 449-458.

Lineweaver, T.T. (2010). Online discussion assignments improve students' class participation. Teaching of Psychology, 37, 204-205.

Lynch, D. J. (2010). Application of online discussion and cooperative learning strategies to online and blended college courses. College Student Journal, 44(3), 777-784.

Maloch, B. (2002). Scaffolding student talk: One teacher>s role in literature discussion groups. Reading Research Quarterly, $37(1), 94-112$.

Marchant, G. J. (2002). Student reading of assigned articles: Will this be on the test? Teaching of Psychology, 29(1), 49-51.

Markel, S. (2001). Technology and education online discussion forums: It's in the response. Online Journal of Distance Learning Administration, 4(2). Retrieved from http://www. westiga.edu/ distance/ojdla/summer42/markel42.html

Marshall, C. \& Rossman, G.B. (1999). Designing qualitative research (3rd ed.). Thousand Oaks: Sage.

Meishar-Tai, H., Kurtz, G. \& Pieterse, E. (2012). Facebook Groups as LMS: A case study. The International Review of Research in Open and Distance Learning, 13(4). Retrieved from_http:// www.irrodl.org/index.php/irrodl/article/view/1294/2295

Mercer, N. (2000). Words and minds. London: Routledge.

Moon, J. A. (1999). Reflection in learning and professional development. London: Kogan Page.

Nadzrah, A. B. \& Kemboja, I. (2009). E-learning environment: Blogging as a platform for language learning. European Journal of Social Sciences, 9(4), 594-604.

Palincsar, A. S., \& Brown, A. L. (1984). Reciprocal Teaching of Comprehension-Fostering -and Comprehension-Monitoring Activities. Cognition and Instruction, 1(2), 117-175.

Pantaleo, S. (2011). Middle years students' collaborative talk about The Red Tree: 'A book that really works your mind'. Australian Journal of Language and Literacy, 34(3), 260-278. 
Pena-Shaff, J., Martin, W., \& Gay, G. (2001). An epistemological framework for analyzing student interactions in computer mediated communication environments. Journal of Interactive Learning Research, 12 (1), 41-68.

Purdy, J. (2008). Inviting conversation: Meaningful talk about texts for English language learners. Literacy, 42(1), 44-51.

Reichenberg, M. (2008). Making Students Talk about Expository Texts. Scandinavian Journal of Educational Research, 52 (1), $17-39$.

Revere, L., \& Kovach, J.V. (2011). Online technologies for engaged learning: A meaningful synthesis for educators. The Quarterly Review of Distance Education, 12(2), 113-124.

Rosenblatt, L. (1978). The reader, the text, the poem: The transactional theory of the literary work. Carbondale, IL: Southern Illinois University Press.

Ross-Gordon, J. (2011). Research on adult learners: Supporting the needs of a student population that is no longer nontraditional. Peer Review, AAC\&U, Winter 2011, 26-29.

Rovai, A. P. (2002). A preliminary look at the structural differences of higher education classroom communities in traditional and ALN courses. Journal of Asychronous Learning Networks, 6(1), 41-56. Retrieved from http://www.sloan-c.org/publications/ jaln/v6n1/v6n1_rovai.asp

Saljo, R. (1982). Learning and understanding: A study of differences in constructing meaning from a text. Goteborg: Acta Universitatis Gothoburgensis.

Sappington, Kinsey, K., \& Munsayac, K. (2002). Two studies of reading compliance among college students. Teaching of Psychology, 29(4), 212-214.

Schroeder, J. \& Greenbowe, T. J. (2009). The chemistry of Facebook: Using social networking to create an online community for the organic chemistry laboratory. Innovate: Journal of Online Education, 5(4). Retrieved from http:// www. Innovateonline.info/print.php?

Selwyn, N. \& Grant, L. (2009). Researching the realities of social software use-an introduction. Learning, Media and Technology, 34, 2, 79-86.

Selwyn, N. (2009). Faceworking: exploring students' educationrelated use of Facebook. Learning, Media and Technology, $34,2,157-174$. 
Shaik Abdullah, S. (2005). Constructing understanding around text: Investigating EFL reading as a social practice. (Unpublished doctoral dissertation). University of Birmingham, UK.

Strauss, A. \& Corbin, J. (1998). Basics of qualitative research: Grounded theory procedures and techniques (2nd ed.). Thousand Oaks: Sage.

Taraban, R., Rynearson, K., \& Kerr, M. (2000). College students' academic performance and self-reports of comprehension strategy use. Reading Psychology, 21, 283-308.

Thomson, D.L. (2010). Teachers' and students' perspectives on how online learning can meet the needs of gifted students. Journal of Advanced Academics, 21(4). 662-712.

Thorne, M. (2000). Extra credit exercise: A painless pop quiz. Teaching of Psychology, 27, 204-205.

Towner, T. \& vanHorn, A. (2007). Facebook: Classroom tool for a classroom community? Paper presented at the annual meeting of the Midwest Political Science Association. Retrieved from http://www.allacademic.com/meta/p197133

Uskul, A. K., \& Eaton, J. (2005). Using graded questions to increase timely reading of assigned material. Teaching of Psychology, 32, 116-118.

Usluel, Y. K. \& Mazman, S. G. (2009). Adoption of Web 2.0 tools in distance education. Procedia Social and Behavioral Sciences, $1,818-823$.

Visagie, S. \& de Villiers, C. (2010). The consideration of Facebook as an academic tool by ICT lecturers across five countries. Retrieved from http://web.up.ac.za/ecis/SACLA2010PR/SACLA 2010/Papers/SACLA_vISAGIE_DEvILLIERS.PDF

Yeh, Y.-C. (2010). Analyzing online behaviors, roles, and learning communities via online discussions. Educational Technology \& Society, 13(1), 140-151. 
